\title{
Zonation of deep-sea decapod fauna in the Catalan Sea (Western Mediterranean)
}

\author{
J. E. Cartes, F. Sardà \\ Institut de Ciències del Mar, Passeig Nacional s/n, E-08039 Barcelona, Spain
}

\begin{abstract}
Zonation of deep-sea decapod crustacean fauna was established in the Catalan Sea (Western Mediterranean) based on a total of 66 bottom trawls carried out between 552 and $2261 \mathrm{~m}$ depth. An OTSB-14 bottom trawl was used as sampling gear. The main boundaries were located at 1200 to $1300 \mathrm{~m}$ and around 1900 to $2000 \mathrm{~m}$. The 1200 to $1300 \mathrm{~m}$ boundary separates the decapod communities dwelling on the middle and lower slopes. The most important causes of decapod zonation in the Mediterranean are more closely linked to trophic factors, in view of the fact that basic hydrographic parameters (temperature, salinity) remain constant along the entire slope. In the Catalan Sea impoverishment of the organic matter content in the bottom sediment with depth and resuspension associated with the steeper portions of the slope (i.e. submarine canyons) are probably the most important factors responsible for the changes recorded. These factors may be directly responsible for the near absence of a variety of organisms that are highly abundant components of the endofauna on the middle slope but disappear below $1200 \mathrm{~m}$. The limits of influence of different macroplanktonic groups (euphausiids, mesopelagic fishes) in the diet of benthic decapods also coincided with the observed boundaries between decapod communities.
\end{abstract}

\section{INTRODUCTION}

Deep-sea decapod crustacean communities have been little studied. Work on this group has traditionally been carried out from a systematic or faunistic perspective. Aspects of a more ecological nature, such as biomass and diversity distribution patterns and faunal zonation, traditional lines of deep-sea research on fish (Rowe \& Menzies 1969, Smith \& Hamilton 1983, Sulak 1984, Lampitt et al. 1986) or on the megafauna in general (Haedrich et al. 1975, 1980, Hecker 1990, etc.), have received little attention in the case of decapod crustaceans. One possible reason might be that decapods are a secondary group in the megabenthic communities in the study areas (deep-sea regions of the North Atlantic and North Pacific) (Haedrich et al. 1975 , 1980, Lampitt et al. 1986). Nevertheless, few such studies have been carried out in tropical or subtropical oceanic zones, where decapod crustaceans form a highly diversified group (Crosnier \& Forest 1973, Abele 1982, Gore 1983, 1984, 1985, Domanski 1986).

Decapod communities on the continental slope have mainly been studied on the upper and middle sub- zones on the slope (Abelló et al. 1988, Markle et al. 1988, Macpherson 1991), whereas studies on the lower slope and in abyssal zones are still more limited (Haedrich et al. 1975, 1980, Wenner \& Boesch 1979).

The general boundaries between megabenthic communities on the different zones of the slope have been established in different works. The limit between the upper slope and the middle slope is variable, ranging between depths of 285 and 653 m (Day \& Pearcy 1968, Haedrich et al. 1975, 1980, Musick 1976). In the Western Mediterranean this boundary ranges between 400 and $500 \mathrm{~m}$ depth (Pérès \& Picard 1964, Abelló et al. 1988).

The boundary between the middle and the lower slope is more uniform and is located at depths between 1000 and 1400 m (Day \& Pearcy 1968, Rowe \& Menzies 1969, Haedrich et al. 1975, 1980, Musick 1976, Lagardère 1977a, Wenner \& Boesch 1979, Hecker 1990). However, boundaries between the depth zones separating different communities are affected by local conditions. Geographic factors are important (Hecker 1990). Even so, the existence of boundaries is a regular phenomenon, though it is not always distinctly observ- 
able (Merrett \& Marshall 1981, Sulak 1984, Snelgrove \& Haedrich 1985), and the boundaries for faunal succession appear to be more pronounced when there is adequate sampling coverage over all depth intervals in a given zone.

Both physical and biological factors have been discussed as causes responsible for faunal zonation with depth. Hydrographic conditions, the steepness of the continental slope, and sedimentation rates are among the major physical factors considered. Resource availability, predator-prey relationships, and interspecific competition are the most important biological factors cited (Rex 1977).

In the Western Mediterranean environmental parameters (temperature, salinity) are fairly constant along the slope below $200 \mathrm{~m}$ (Hopkins 1985). Dissolved oxygen presented minima between 200 and $1000 \mathrm{~m}$ in the water column, where seasonal changes were reported (Jacobsen 1912). Muddy sediments predominate on the slope, although in the upper part of the Balearic Basin sediments are terrigenous, whereas in the deeper part biogenic deposits are more important (Emelyanov 1972). The upper and middle slope is heavily incised by numerous submarine canyons (Monaco et al. 1990). Decapod crustaceans are a dominant group in terms of abundance at depths between 600 and $2200 \mathrm{~m}$ in the Catalan Sea (Western Mediterranean) (Cartes 1991, Cartes \& Sardà 1992). In view of the extremely important role of decapods in the study area, the object of the present study was to determine the structure of communities and zonation in relation to depth for the deep-sea decapod taxocenosis in the Catalan Sea. Possible causes of the zonation pattern observed for these communities are also discussed.

\section{MATERIAL AND METHODS}

A total of 61 bottom trawls were carried out at depths of 862 to $2261 \mathrm{~m}$ in the period 1985 to 1989 in the Catalan Sea between Catalonia and the Balearic Islands (Fig. 1). Sampling locations have been described elsewhere (Cartes 1993). Maximum depth in the study area is around $2300 \mathrm{~m}$. Sampling at depths below $862 \mathrm{~m}$ was uniform and continuous (Table 1). A further 6 bottom trawls were carried out on the middle slope at depths between 552 and $669 \mathrm{~m}$ for purposes of comparison.

An OTSB-14 bottom trawl equipped with 2 doors and a single bridle (Merrett \& Marshall 1981, Sulak 1984) was used as the sampling gear. The size of the OTSB14 trawl at a towing speed of 2.5 knots was estimated as $1.5 \mathrm{~m}$ for the vertical opening and $7 \mathrm{~m}$ for the distance between the wings. These measurements were

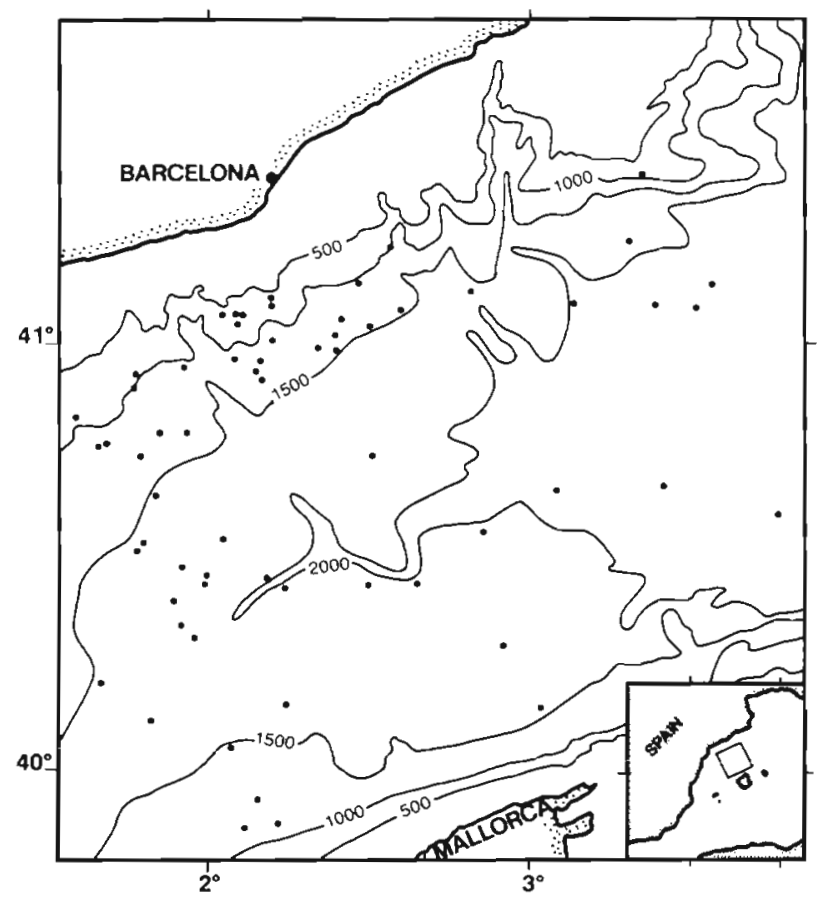

Fig. 1. Location of bottom trawls carried out in the Catalan Sea

verified with the aid of a remote acoustic sensing system attached to the gear (unpubl. data) and were approximately the same as those reported by Sulak (1984). The end of the net was equipped with a $6 \mathrm{~mm}$ mesh inside codend liner. All the samples were collected on board the RV 'García del Cid'.

Species abundance was calculated for each sample after standardization of the results to a $1 \mathrm{~h}$ tow. Analysis of the sampling data was carried out by cluster analysis applied to all hauls and all species com-

Table 1. Distribution of trawls carried out in this study by $100 \mathrm{~m}$ depth interval

\begin{tabular}{|cc|}
\hline Depth $(\mathrm{m})$ & No. of samples \\
\hline 600 & 6 \\
1000 & 9 \\
1100 & 5 \\
1200 & 3 \\
1300 & 6 \\
1400 & 3 \\
1500 & 4 \\
1600 & 5 \\
1700 & 8 \\
1800 & 2 \\
2000 & 2 \\
2100 & 1 \\
2200 & 4 \\
Total & 67 \\
\hline
\end{tabular}




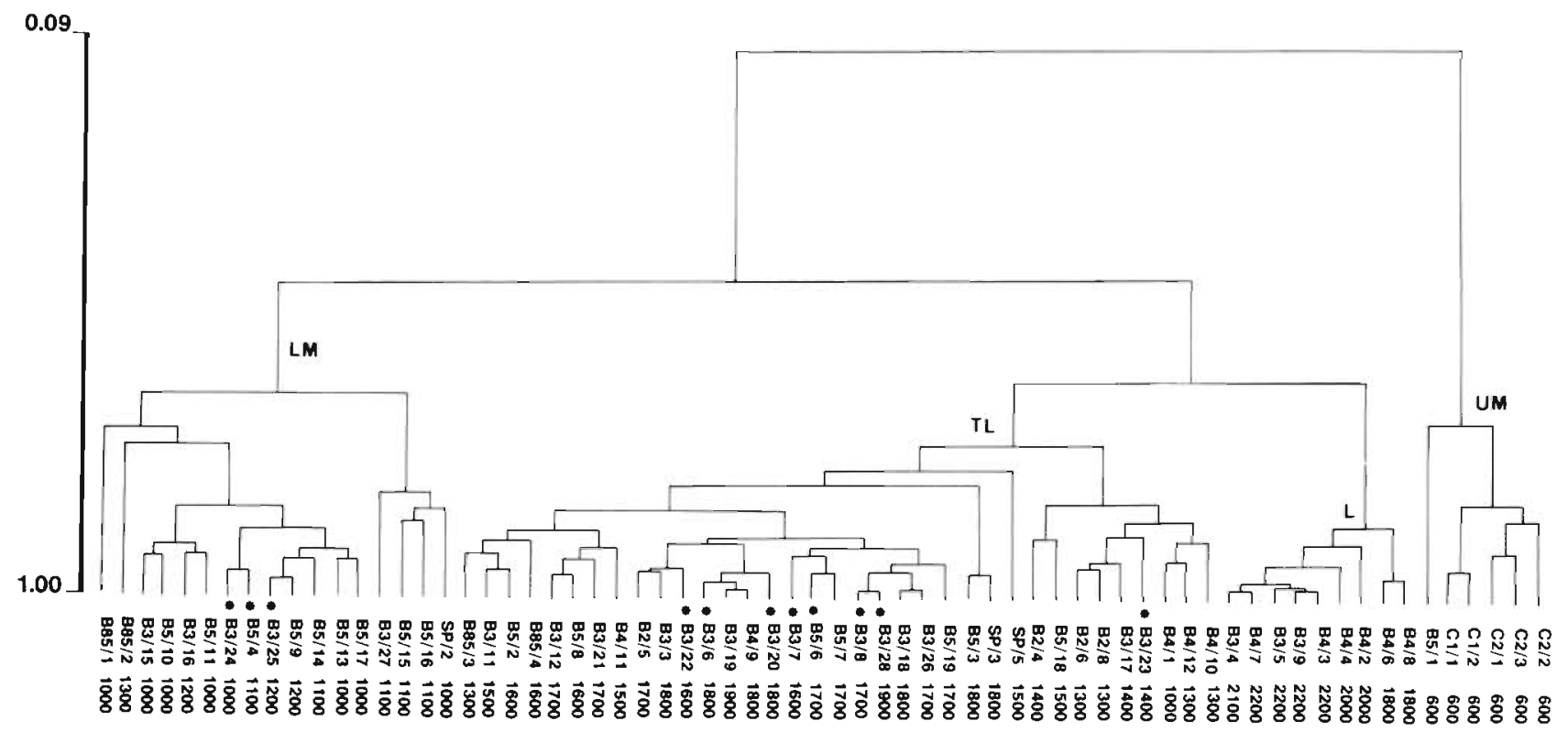

Fig. 2. Cluster analysis of all trawls performed on the deep-sea slope in the Catalan Sea. The mean depth of each sampling station, rounded to the nearest $100 \mathrm{~m}$ isobath, is also indicated. (*): Samples carried out on the eastern slope in the Balearic Islands (see Fig. 1). UM: upper-middle slope; LM: lower-middle slope; TL: transitional lower slope; L: lower slope

bined as well as by reciprocal averaging analysis following log transformation $[\ln (x+1)]$ of the abundance and biomass data. Previously uncommon species that occurred only 1 time in the samples were removed from the data matrix. The cluster analysis performed used linear correlation as a measure of similarity and UPGMA as the aggregation algorithm (Lleonart \& Roel 1984). Reciprocal averaging analysis was applied to the same data matrix, but only for hauls carried out at depths below $862 \mathrm{~m}$.

Biomass values were calculated for the different depth strata taking as the centre point for each depth interval $(600$ to $2200 \mathrm{~m}$ ) the multiple of $100 \mathrm{~m}$ nearest to the centre. Cluster analysis based on linear correlation-UPGMA was also applied to these data.

\section{RESULTS}

Analysis of the trawl results yielded groupings of samples according to trawl depth (Fig. 2). The first of the identifiable groups consisted of 6 samples taken around the $600 \mathrm{~m}$ isobath (552 to $669 \mathrm{~m}$ ) on the uppermiddle slope (UM). The samples collected at depths greater than $862 \mathrm{~m}$ presented a number of groups. The approximate depth boundaries of the first group were 862 and $1200 \mathrm{~m}$. This grouping has been associated with the communities on the lower-middle slope (LM). The separation between the clusters for the samples on the upper-middle and lower-middle slopes was the result of the lack of continuity in sampling between
669 and $862 \mathrm{~m}$. Nevertheless, the dominant species in these 2 zones are common to both (Pérès \& Picard 1964, Pérès 1985, Abelló et al. 1988, Cartes \& Sardà 1992). Bathyal decapod communities on the middle slope in the Catalan Sea dwell at depths between 500 and $1300 \mathrm{~m}$. Certain species, like Calocaris macandreae, Plesionika martia, and Acanthephyra eximia, underwent major changes in density over the middle slope, and in fact this zone should be subdivided into a further 2 subzones (upper and lower) according to the results reported for other regions (Musick 1976, Haedrich et al. 1980). At depths below $1300 \mathrm{~m}$ there was a homogeneous group that consisted of the hauls carried out on the deep lower slope below $2000 \mathrm{~m}$ (L). although this group also included 2 hauls carried out at shallower depths. This group was separate from the samples taken on the transition zone on the lower slope (TL) between 1300 and $1900 \mathrm{~m}$. Both these groups together made up the lower-slope decapod communities. The most typically characteristic lowerslope communities dwelled at depths below $2000 \mathrm{~m}$.

The species analysis disregarded those species recorded only in a single haul and produced coherent groups (Fig. 3). The first group comprised the bathyal community on the deep lower slope, including abundant species like Acanthephyra eximia, Stereomastis sculpta and Nematocarcinus exilis, together with rarer species like Chaceon mediterraneus and the unidentified Axiid (cf. Cartes \& Sardà 1992). Lastly, certain bathypelagic species like Acanthephyra pelagica and Sergia robusta were also included in this group. 


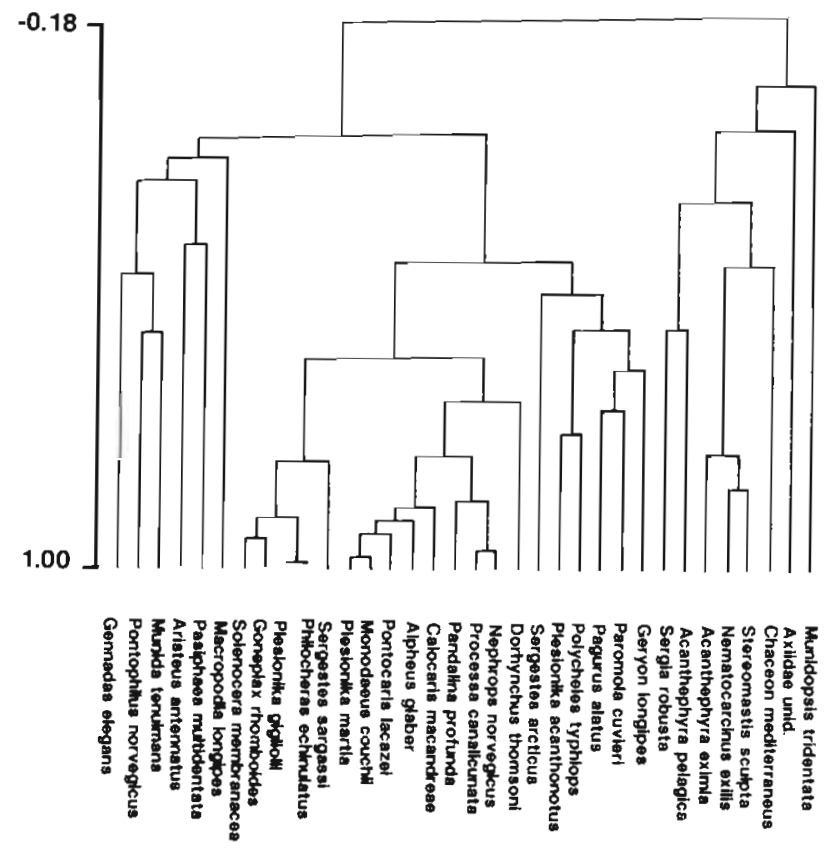

Fig. 3. Cluster analysis of species

The next group comprised the species that were most abundant in the hauls carried out on the transition zone (TL), on the lower-middle slope (LM), and on the upper-middle slope (UM). However, the results of species analysis must be viewed with caution due to the sampling discontinuity in the 669 to $862 \mathrm{~m}$ depth range. Furthermore, the entire depth distribution

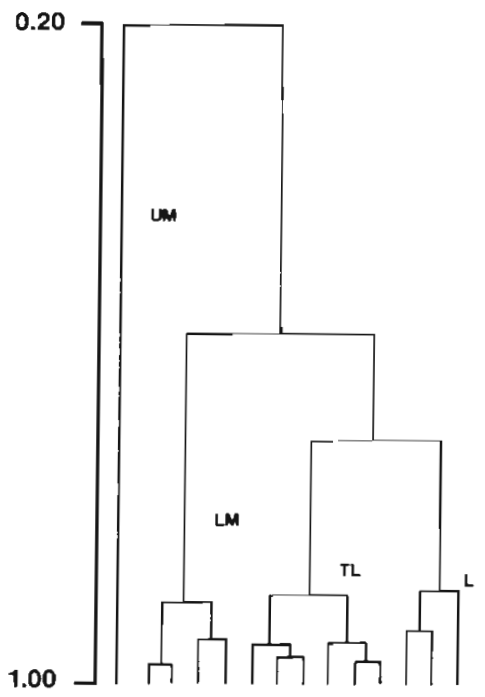

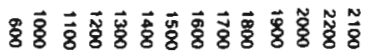

Fig. 4. Cluster analysis of biomass (biomass results calculated per $100 \mathrm{~m}$ depth interval). UM: upper-middle slope; LM: lower-middle slope; TL: transitional lower slope; L: lower slope range of these species was not fully covered. Thus, such species as Aristeus antennatus, Pontophilus norvegicus, and Munida tenuimana appeared to be characteristic of the bathyal communities on the middle slope. These species were cited by Abelló et al, (1988) as typical on the slope at depths between 500 and $800 \mathrm{~m}$.

The results of biomass analysis also yielded structured groups according to depth (Fig. 4). The groups corresponded to the depth intervals of $600 \mathrm{~m}$ (UM), 1000 to $1300 \mathrm{~m}$ (LM), 1400 to $1900 \mathrm{~m}$ (TL), and 2000 to $2200 \mathrm{~m}$ (L). These groups conformed nearly exactly to those from the analysis of species abundance in the hauls (Fig. 2).

The results of reciprocal averaging analysis for the hauls and the species identified are given in Fig. 5, relating the mean depth of each sample to the values of the first axis. The first axis is distinctly related to depth. The eigenvalue of the first axis is 0.529 and accounted for $40.0 \%$ of the analysis variance. The cumulative variance of the first 3 axes was $61.7 \%$. The resulting point distribution indicated 2 inflection points at depths of from 1200 to $1300 \mathrm{~m}$ and from 1900 to $2000 \mathrm{~m}$. These inflection points reflected the increased rate of faunal change over comparable changes in depth (Wenner \& Boesch 1979).

Species were plotted according to their position in the different depth strata. On the whole, the results were similar to those for the cluster analysis by species.

\section{DISCUSSION}

All the analyses carried out have pointed to a zonation pattern for the decapod crustacean taxocenosis in the Catalan Sea. The main boundary was located at 1200 to $1300 \mathrm{~m}$ ( 1300 to $1400 \mathrm{~m}$ for the biomass results), with a secondary boundary located at around 1900 to $2000 \mathrm{~m}$ in depth. Based on the species composition (Cartes \& Sarda 1992) and on the structure of the communities reported earlier for the Western Mediterranean (Pérès 1985, Abelló et al. 1988), the first boundary (1200 to $1300 \mathrm{~m}$ ) separates the decapod communities dwelling on the middle and lower slopes. Predominance of Acanthephyra eximia, Nematocarcinus exilis and Stereomastis sculpta in terms of both abundance and biomass (Cartes \& Sardà 1992) was characteristic of the lower slope, which is equivalent to the lower subzone defined by Pérès (1985). The most typical lower-slope communities dwelled at depths below $2000 \mathrm{~m}$.

Local geographic conditions are responsible for the location of depth boundaries between communities (Hecker 1990). This effect was observed in the associations among the hauls carried out on the lower slope 


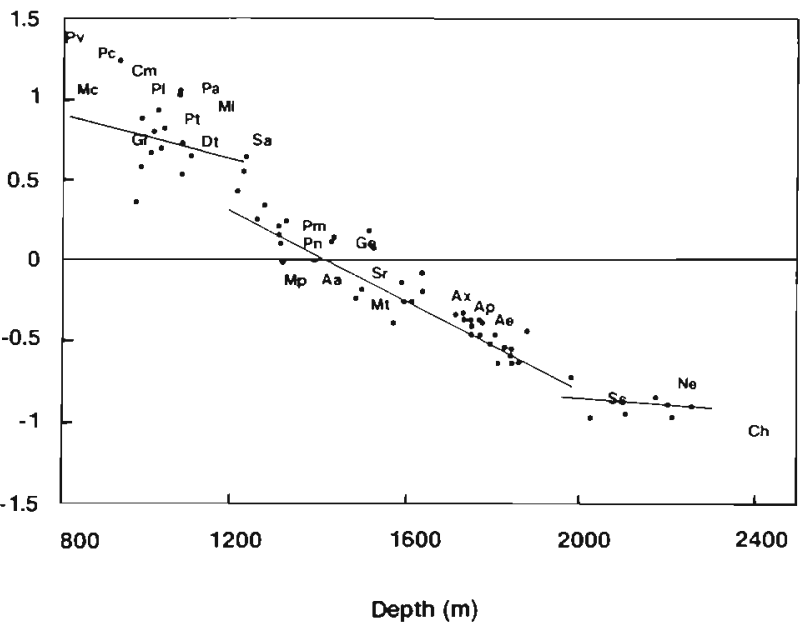

Fig. 5. Reciprocal averaging analysis (distribution of species and trawls along the first axis versus the mean depth of each trawl). Aa: Aristeus antennatus; Ae: Acanthephyra eximia; Ap: Acanthephyra pelagica; Ax: Axiidae unidentified; Ch: Chaceon mediterraneus; Cm: Calocaris macandreae; Dt: Dorhynchus thomsoni; Ge: Gennadas elegans; Gl: Geryon longipes; Mc: Monodaeus couchij; Ml: Macropodia longipes; Mp: Munida tenuimana; Mt: Munidopsis tridentata; Ne: Nematocarcinus exilis; $\mathrm{Pa}$ : Plesionika acanthonotus; $\mathrm{PC}$ : Paromola cuvieri; Pl: Plesionika martia; Pm: Pasiphaea multidentata; Pn: Pontophilus norvegicus; Pt: Polycheles typhlops; Pv: Pagurus alatus; Sa: Sergestes arcticus; Sr: Sergia robusta; Ss: Stereomastis sculpta

around the Balearic Islands, which formed certain separate aggregation in the clusters. A low level of geographical homogeneity in samples may prove a problem in delimiting the boundaries between communities, because a given boundary determined by a given set of factors may be located at differing depths depending on local conditions.

The boundary between the middle and lower slopes is distinctly variable in location (Day \& Pearcy 1968, Rowe \& Menzies 1969, Haedrich et al. 1975, 1980, Musick 1976, Lagardère 1977a, Wenner \& Boesch 1979, Hecker 1990). These studies have been carried out on different megafaunal communities, as well as on different taxocenoses (fish, decapods). Also, trophic factors exert an influence on species zonation through competitive interactions (Rex 1977), which are stronger between groups at higher trophic levels. Therefore, the boundaries between megabenthic communities in general, or between fish, decapod, and echinoderm communities, may not coincide because of the different trophic strategies employed by each group (Haedrich et al. 1980). This same phenomenon occurred in the Catalan Sea when comparing the zonation of decapod crustaceans and fish (Stefanescu et al. in press), which only partially shared the main boundary around $1300 \mathrm{~m}$. This may have been the result of the different feeding habits and prey selection (mainly due to prey size) of these 2 megafaunal groups. The diet of fish on the lower slope is more heavily slanted towards the capture of mobile benthopelagic prey (Gordon \& Mauchline 1990), whereas the diet of decapod crustaceans is based more on the capture of epibenthic and endobenthic prey (Cartes \& Sardà 1989. Cartes 1991, Cartes \& Abelló 1992).

Hydrographic conditions would appear to be another cause of change in environmental conditions at the boundary between the upper and middle slope (Haedrich et al. 1975, Abelló et al. 1988). Intermediate Mediterranean water, submitted to certain seasonal hydrographic changes (Jacobsen 1912), is present above the upper slope in the Catalan Sea and may be responsible for the boundary (around 400 to $500 \mathrm{~m}$ ) between the upper and middle slopes (Abelló et al. 1988). The $1200 \mathrm{~m}$ boundary is not linked to such conditions, because of the high hydrological (temperature, salinity, dissolved oxygen) stability of the deep-water masses in the Mediterranean Sea (Jacobsen 1912, Hopkins 1985). Changes in the degradation of organic matter with depth are also important, both as concerns the vertical downward drift through the water column (Wishner 1980) and the organic matter content on the slope (Carpine 1970, Drake et al. 1978, Rowe et al. 1982). The high constant temperature in the deep-sea Mediterranean are conducive to a rapid degradation of organic matter during the sedimentation process in which it drifts down to the lower slope, as postulated previously for the Red Sea (Wishner 1980) and the Mediterranean (Stefanescu et al. in press).

The most important causes of decapod zonation in the Mediterranean are probably more closely linked to trophic factors. The middle slope, particularly the upper subzone, is characterized by relatively eutrophic conditions, because of the local influence of the submarine canyons. The trophic group composed by deposit feeders is always well represented in eutrophic zones (Sokolova 1972), and in the Catalan Sea a number of endobenthic species are important on the middle slope, including Calocaris macandreae (Cartes 1991), which is a sedimentivorous species (Carpine 1970), echinoderms (e.g Molpadia musculus, Brissopsis lyrifera) and the bivalve Abra longicallus. The lower limit to the distribution range of all these species is $1000 \mathrm{~m}$ (Carpine 1970). These species are not present below $1200 \mathrm{~m}$, nor are they replaced by similar species (Carpine 1970, Cartes 1991, Cartes \& Sardà 1992). In contrast, oligotrophic conditions in the lower subzone seem pronounced, giving rise to the presence of suspension feeders like sponges (Uriz \& Rosell 1990), polyps of medusae Stephanoscyphus spp., cirripeds Scalpellum sp., and the asteroid Brisingella coronata (Fredj \& Laubier 1985, Alvà 1987), which are more typical of oligotrophic oceanic regions (Sokolova 
1972). A decrease in the concentration of organic matter in the bottom sediment from $700 \mathrm{~m}$ has been reported in the Northwestern Mediterranean (Carpine 1970). The nature of the recently deposited upper layer of bottom sediment also changes. On the outlying edges of the Catalan Sea the sediment is terrigenous and continental in origin. In contrast, the sediment in the deeper central part of the Catalan-Balearic Basin consists of biogenic deposits originating from globigerina and pteropods (Emelyanov 1972, Fredj \& Laubier 1985). The upper and middle slopes would also benefit from the presence of submarine canyons where resuspension of organic matter is important because of the existence of periodical up-and down-canyon bottom currents (cf. Shepard et al. 1974, Monaco et al. 1990).

The macrobenthos is the chief source of available resources for decapod crustaceans. Different authors have reported a general tendency for the benthos biomass (Sanders \& Hessler 1969), macrobenthos (Rowe 1983), and meiobenthos (Thiel 1983) to decrease markedly with depth, and data have been provided for the deep-sea Mediterranean macrofauna (Jumars \& Gallagher 1982, Pérès 1985). There is aiso a generalized decrease in macrofaunal size with depth (Jumars \& Gallagher 1982, Sokolova 1990) that also occurrs in the deep-sea Mediterranean (Chardy et al. 1973, Pérès 1985). Decrease in the size of available resources is probably related to the decrease in the mean weight of decapod crustaceans with depth in the Catalan Sea (Sardà \& Cartes 1993).

Another important trophic factor that must affect the existing zonation of decapod crustaceans in the Catalan Sea at around 1200 to $1300 \mathrm{~m}$ is a possible reduction in the density of the benthic boundary layer (BBL) parallel to that reported in the NE Atlantic (Hargreaves 1984, Hargreaves et al. 1984) and probably related to the lack of resuspended organic matter (Angel 1990) due to turbidity currents and sediment slides (Sedberry \& Musick 1978, Tyler 1988). Based on our own data the limits of influence of different macroplanktonic groups in the diet of benthic decapods were detected in the Catalan Sea (Cartes 1991). The lower limit for mesopelagic fish and euphausiids Meganyctiphanes norvegica is located at around 1200 to $1300 \mathrm{~m}$ and for siphonophores and hyperids at around $2000 \mathrm{~m}$ (Cartes 1991) coinciding with the boundaries observed for decapod communities and, in part, for fish communities as well (Stefanescu et al. in press). The $1200 \mathrm{~m}$ boundary approximately coincides with the commonly accepted limit to the influence of the mesopelagic fauna on benthic slope species (around $1000 \mathrm{~m}$ ) generally (Lagardère 1977a, Sedberry \& Musick 1978) as well as in the Mediterranean (Bernard 1958, Pérès 1958, Goodyear et al. 1972). The existence of a benthopelagic fauna close to the bathyal bottoms
(Marshall \& Merrett 1977, Wishner 1980, Hargreaves 1984) was linked to resuspension phenomenon (Angel 1990). The low level of resuspended organic matter might account for the disappearance of macroplanktonic components such as the euphausid $M$. norvegica, an omnivorous species (Mauchline 1980). Resuspension would be particularly important in the Catalan Sea down to $1000 \mathrm{~m}$, because of the multiplicity of submarine canyons in this area (Reyss 1971).

In summary, zonation of the Mediterranean deepsea decapods is probably the result of a set of physical and biological factors which are difficult to quantify. However and in our opinion, in the Catalan Sea, in view of the fact that environmental parameters such as temperature and salinity remain constant, resuspension associated with canyons and the steeper portions of the slope and the impoverishment of the organic matter content in the bottom sediments with depth are probably the most important factors responsible for the changes in bathyal biocenoses recorded with depth. These factors exert a direct influence on biological aspects like the near absence below $1200 \mathrm{~m}$ of organisms that are highly abundant components of the endofauna on the middle slope (Carpine 1970, Cartes \& Sardà 1992), and the limits of influence on the diet of benthic decapods established by various macroplanktonic groups, which coincided with the observed boundaries in decapod communities. The last phenomenon was probably also related to the boundary between 1000 and $1300 \mathrm{~m}$ in other oceanic areas (Lagardère 1977b, Mauchline \& Gordon 1991).

Acknowledgements. The authors express their appreciation to all the members of the deep-sea research programs 'Batimar' (CSIC-CAYCIT, ref. PB90-0166), 'Abismar', 'Pont 89 ' and 'Pont 90' (CICYT) for their collaboration. Thanks to Mr R. Sacks who prepared the English translation and to Mrs G. Fuster and to Mr J. M. Anguita for their technical assistance in preparing the figures.

\section{LITERATURE CITED}

Abele, L. G. (1982). Biogeography. In: Bliss, D.E. (ed.) The biology of Crustacea. Vol. 1. Academic Press, London, p. $242-304$

Abello, P., Valladares, F. J., Castellon. A. (1988). Analysis of the structure of decapod crustacean assemblages off Catalan coast (North-West Mediterranean). Mar. Biol. 98: $39-49$

Alvà, V. (1987). Equinodermos batiales de la cubeta catalanobalear (Mediterráneo Noroccidental). Miscelánea zool. 11 202-211

Angel, M. V. (1990). Life in the benthic boundary layer: connections to the mid-water and sea floor. Phil. Trans. R. Soc. Lond. 331. 15-28

Bernard, F. (1958). Plancton et benthos observés durant trois plongées en bathyscaphe au large de Toulon. Annls Inst. océanogr., Monaco 35: 287-325 
Carpine, C. (1970). Ecologie de l'étage bathyal dans la Méditerranée occidentale. Mém. Inst. océanogr. Monaco 2: $1-146$

Cartes, J. E. (1991). Analisis de las comunidades y estructura trófica de los Crustáceos Decápodos batiales del Mar Catalán. Tesis, Univ. Politécnica de Catalunya, Barcelona

Cartes, J. E. (1993). Deep-sea decapod fauna of the Western Mediterranean: bathymetric distribution and biogeographic aspects. Crustaceana (in press)

Cartes, J. E., Abello, P. (1992). Comparative feeding habits of polychelid lobsters in the Western Mediterranean deepsea communities. Mar. Ecol. Prog. Ser. 84:139-150

Cartes, J. E., Sarda, F. (1989). Feeding ecology of the deepwater aristeid crustacean Aristeus antennatus. Mar. Ecol. Prog. Ser. 54: 229-238

Cartes, J. E., Sarda, F. (1992). Abundance and diversity of Decapod Crustaceans in the deep-Catalan Sea (Western Mediterranean). J. nat. Hist. 26: 1305-1323

Chardy, P., Laubier, L., Reyss, D., Sibuet, M. (1973). Donnés préliminaires sur les résultats biologiques de la campagne Polymède I. Dragages profonds. Rapp. P.-v. Réun. Comm. int. Explor. scient. Mer Méditerr. 21: 621-625

Crosnier, A., Forest, J. (1973). Les crevettes profondes de l'Atlantique oriental tropical. Faune trop. O.R.S.T.O.M 19: $1-409$

Day, D. S., Pearcy, W. G. (1968). Species associations of benthic fishes on the continental shelf and slope off Oregon. J. Fish. Res. Bd Can. 25: 2665-2675

Domanski, P. (1986). The near-bottom shrimp faunas (Decapoda: Natantia) at two abyssal sites in the Northeast Atlantic Ocean. Mar. Biol. 93: 171-180

Drake, D. E., Hatcher, P. G., Keller, G. H. (1978). Suspended particulate matter and mud deposition in upper Hudson Submarine Canyon. In: Stanley, D. J., Kelling, G. (eds.) Sedimentation in submarine canyons, fans and trenches. Dowden, Hutchinson \& Ross, Stroudsburg, p. 33-41

Emelyanov, E. M. (1972). Principal types of recent bottom sediments in the Mediterranean Sea: their mineralogy and geochemiestry. In: Stanley, D. J. (ed.) The Mediterranean Sea: a natural sedimentation laboratory. Dowden, Hutchinson and Ross, Stroudsburg, p. 355-386

Fredj, G., Laubier, L. (1985). The deep Mediterranean benthos. In: Moraitou-Apostolopoulou, M., Kiortsis, V. (eds.) Mediterranean marine ecosystems. Plenum Press, New York, p. 109-146

Goodyear, R. H., Zahurancec, B. J., Pugh, L. W., Gibbs, R. H. $\mathrm{Jr}$ (1972). Ecology and vertical distribution of Mediterranean midwater fishes. Mediterranean Biological Studies, Final Report, Part III. Smithsonian Inst., Washington, DC, p. 91-229

Gordon, J. D. M., Mauchline, J. (1990). Depth-related trends in diet of a deep-sea bottom-living fish assemblage of the Rockall Trough. In: Barnes, M., Gibson, R. N. (eds.) Trophic relationships in the marine environment. Proc. 24th European Mar. Biol. Symp. Aberdeen University Press, Aberdeen, p. 439-452

Gore, R. H. (1983). Notes on rare species of Munidopsis (Anomura: Galatheidae) and Ethusina (Brachyura: Dorippidae) collected by the USNS 'Bartlett' in the Venezuela Basin, Caribbean Sea. Proc. Acad. nat. Sci. Philad. 135: 200-217

Gore, R. H. (1984). Notes on abyssal lobsters, genus Willemoesia (Palinura, Polychelidae) collected by USNS 'Bartlett' from the Venezuela Basin, Caribbean Sea. Proc. Acad nat. Sci. Philad. 136: 1-11

Gore, R. H. (1985). Abyssobenthic and abyssopelagic Penaeoidean shrimp (Families Aristidae and Penaeidae) from the Venezuela Basin, Caribbean Sea. Crustaceana 49 (2): $120-138$

Haedrich, R. L., Rowe, G. T., Polloni, P. T. (1975). Zonation and faunal composition of epibenthic populations on the continental slope south of New England. J. mar Res. 33 : $191-212$

Haedrich, R. L., Rowe, G. T., Polloni, P. T (1980). The megabenthic fauna in the deep sea south of New England, USA. Mar. Biol. 57. 165-179

Hargreaves, P. M. (1984). The distribution of Decapoda (Crustacea) in the open ocean and near-bottom over an adjacent slope in the northern North-east Atlantic ocean during Autumn 1979. J. mar. Biol. Ass. U.K. 64: 829-857

Hargreaves, P. M., Ellis, C. J., Angel, M. V. (1984). An assessment of biological processes close to the sea bed in a slope region and its significance to the assessment of sea bed disposal of radiactive waste. Institute of Oceanographic Sciences Rep. 185, Wormley

Hecker, B. (1990). Variation in megafaunal assemblages on the continental margin south of New England. Deep Sea Res. $37(1): 37-57$

Hopkins, T. S. (1985). Physics of the sea. In: Margalef, R. (ed.) Key environments: Western Mediterranean. Pergamon Press, New York, p. 100-125

Jacobsen, J. P. (1912). The amount of oxygen in the water of Mediterranean. In: Schmidt, J. (ed.) Report on the Danish Oceanographical Expeditions 1908-1910 to the Mediterranean and adjacent seas, Vol. I : Introduction, hydrography, deposits of the sea bottom. Andr. Fred. Host \& Son, Copenhagen, p. 207-236

Jumars, P. A., Gallagher, E. D. (1982). Deep-sea community structure: three plays on the Benthic Proscenium. In: Ernst, W. G., Morin, V G. (eds.) The environment of the deep-sea. Prentice-Hall, Englewood Cliffs, p. 217-254

Lagardère J. P. (1977a). Recherches sur la distribution verticale et sur l'alimentation des crustaces decapodes benthiques de la Pente Continentale du Golfe de Gascogne. Analyse des groupements carcinologiques. Bull. Cent. Etud. Rech. scient. Biarritz. 11 (4) : $367-440$

Lagardère, J. P. (1977b). Recherches sur le régime alimentaire et le comportement prédateur dés Decapodes Benthiques de la Pente Continentale de l'Atlantique Nord Oriental (Golfe de Gascogne et Maroc). In: Keegan, B. F., Ceidigh, P. O., Boaden, P. S. J. (eds.) Biology of benthic organisms. Pergamon Press, New York, p. 397-408

Lampitt, R. S., Billett, D. S. M., Rice, A. L. (1986). Biomass of the invertebrate megabenthos from 500 to $4100 \mathrm{~m}$ in the northeast Atlantic Ocean. Mar. Biol. 93: 69-81

Lleonart, J., Roel, B. (1984). Análisis de las comunidades de peces y crustáceos demersales de la costa de Namibia (Atlántico Suroriental). Investigacion Pesq. 48: 187-206

Macpherson, E. (1991). Biogeography and community structure of the decapod crustacean fauna off Namibia (Southeast Atlantic). J. crust. Biol. 11 (3): 401-415

Markle, D. F., Dadswell, M. J., Halliday, R. G. (1988). Demersal fish and decapod crustacean fauna of the upper continental slope off Nova Scotia from La Have to Sr. Pierre Banks. Can. J. Zool. 66: 1952-1960

Marshall, N. B., Merrett, N. R. (1977). The existence of a benthopelagic fauna in the deep sea. In: Angel, $M$. (ed.) A voyage of discovery. Pergamon Press, Oxford, p. $483-497$

Mauchline, J. (1980). The biology of mysids and euphausiids. In: Blaxter, J. H. S., Russell, F. S., Yonge, M. (eds.) Advances in marine biology, vol. 18. Academic Press, London, p. 443-458

Mauchline, J., Gordon, J. D. M. (1991). Oceanic pelagic prey 
of benthopelagic fish in the benthic boundary layer of a marginal oceanic region. Mar. Ecol. Prog. Ser. 74: 109-115

Merrett, N. R., Marshall, N. B. (1981). Observations on the ecology of deep-sea bottom-living fishes collected off northwest Africa $\left(08^{\circ}-27^{\circ} \mathrm{N}\right)$. Prog. Oceanogr 9: $185-244$

Monaco, A., Biscaye, P., Soyer, J., Pocklington, R., Heussner, S. (1990). The Gulf of Lions' hydrodynamics. Cont. Shelf Res. 10(9-11): 809-839

Musick, J. A. (1976). Comunity structure of fishes on the continental slope and rise off the middle Atlantic coast of the U.S. Joint Oceanographic Assembly, Edinburgh

Pérès, J. M. (1958). Remarques générales sur un ensemble de quinze plongées effectuées avec le bathyscaphe F.N.R.S. III. Annls Inst. Océanogr. Monaco 35: 259-285

Pérès, J. M. (1985). History of the Mediterranean biota and the colonization of the depths. In: Margalef, R. (ed.) Key environments: Western Mediterranean. Pergamon Press, New York, p. 198-232

Pérès, J. M., Picard, J. (1964). Nouveau manuel de bionomie benthique de la Mer Méditerranée. Recl Trav. Stn mar. Endoume 31(47): 1-137

Rex, M. A. (1977). Zonation in deep-sea gastropods: the importance of biological interactions to rates of zonation. In: Keegan, B. F., Ceidigh, P. O., Boaden, P. J. S. (eds.) Biology of benthic organisms. Pergamon Press, New York, p. $521-530$

Reyss, D. (1971). Les canyons sous-marins de la mer Catalane: le rech du Cap et le rech Lacaze-Duthiers. III. Les peuplements de macrofaune benthique. Vie Milieu 22: 529-613

Rowe, G. T. (1983). Biomass and production of the deep-sea macrobenthos. In: Rowe, G. T. (ed.) Deep-sea biology. The sea, vol. 8. John Wiley \& Sons, New York, p. 97-121

Rowe, G. T., Menzies, R. J. (1969). Zonation of large benthic invertebrates in the deep-sea off the Carolinas. Deep Sea Res. 16: 531-537

Rowe, G. T., Polloni, P. T., Haedrich, R. L. (1982). The deepsea macrobenthos on the continental margin of the northwest Atlantic Ocean. Deep Sea Res. 29: 257-278

Sanders, H. L., Hessler, R. R. (1969). Ecology of the deep-sea benthos. Science 162: 1419-1424

This article was submitted to the editor
Sardà, F., Cartes, J. E. (1993). Relationship between size and depth in decapod populations on the slope between 900 and $2200 \mathrm{~m}$ in the western Mediterranean. Deep Sea Res. (in press)

Sedberry, G. R., Musick, J. A. (1978). Feeding strategies of some demersal fishes of the continental slope and rise off the mid-Atlantic coast of the USA. Mar. Biol. 44: 357-375

Shepard, F. P., Marshall, N. F., McLoughlin, P. A. (1974). Currents in submarine canyons. Deep Sea Res. 21: $691-706$

Smith, C. R., Hamilton, S.C. (1983). Epibenthic megafauna of a bathyal basin off southern California: patterns of abundance, biomass, and dispersion. Deep Sea Res. 30(9A): $907-928$

Snelgrove, P. V. R., Haedrich, R. L. (1985). Structure of the deep demersal fish fauna off Newfoundland. Mar. Ecol. Prog. Ser. 27: 99-107

Sokolova, M. N. (1972). Trophic structure of deep-sea macrobenthos. Mar. Biol. 16: 1-12

Sokolova, M. N. (1990). On the size of the deep-sea macrobenthic invertebrates. Prog. Oceanogr. 24: 251-252

Stefanescu, C., Lloris, D., Rucabado, J. (in press). Deep-sea fish assemblages in the Catalan Sea (western Mediterranean). Deep Sea Res.

Sulak, K. J. (1984). A comparative ecological analysis of temperate and tropical demersal deep-sea fish faunas in the western North Atlantic. Ph.D. dissertation, Univ. of Miami

Thiel, H. (1983). Meiobenthos and nanobenthos of the deep sea. In: Rowe, G. T. (ed.) Deep-sea biology. The sea vol. 8. John Wiley \& Sons, New York, p. 167-230

Tyler, P. A. (1988). Seasonality in the deep sea. Oceanogr. mar. Biol. A. rev. 26: 227-258

Uriz, M. J., Rosell, M. D. (1990). Sponges from bathyal depths $(1000-1750 \mathrm{~m})$ in the Western Mediterranean. J. nat. Hist. 24: 373-391

Wenner, E. L., Boesch, D. F. (1979). Distribution patterns of epibenthic decapod Crustacea along the shelf-slope coenocline, Middle Atlantic Bight, USA. Bull. biol. Soc. Wash. 3: $106-133$

Wishner, K. F. (1980). The biomass of the deep-sea benthopelagic plankton. Deep Sea Res. 27A: 203-216

Manuscript first received: April 24, 1992

Revised version accepted: January 5, 1993 